\title{
Adopting Occupational Health and Safety Management Standards: The Impact on Financial Performance in Pharmaceutical Firms in China
}

This article was published in the following Dove Press journal: Risk Management and Healthcare Policy

\author{
Minghui Yang $\mathbb{D}^{1,2}$ \\ Petra Maresova (iD) ${ }^{\prime}$ \\ 'Faculty of Informatics and Management, \\ University of Hradec Kralove, Hradec \\ Kralove 50003, Czech Republic; \\ ${ }^{2}$ International Business School, \\ Guangzhou College of South China \\ University of Technology, Guangzhou, \\ Guangdong 510800, People's Republic of \\ China
}

Background and Purpose: In recent years, the frequent occurrence of occupational accidents, illness, and injuries has become a major issue in China. This study aims to investigate the relationship between the adoption of Occupational Health and Safety Management System (OHSMS) standards and financial performance, with a particular focus on the pharmaceutical firms in China.

Methods: The study is based on a sample consisting of 125 pharmaceutical firms listed on the Shanghai and the Shenzhen stock exchanges in China for the period 2010-2018. Each sample firm was evaluated by whether and when it is certified by an OHSMS standard depending on secondary data collected from an independent certification database. Panelbased regression models were employed to explore whether adoption of an OHSMS standard has had an impact on financial performance.

Results: The regression results reveal that the adoption of an OHSMS standard positively affects contemporaneous financial performance measured by return on assets (ROA), return on equity (ROE), and earnings per share (EPS). Mixed results were found when financial performance indicators were extended by two years, suggesting that ROE will increase in the second year after a firm is certified with the standard, but EPS will decline in the third year.

Conclusion: The study findings empirically show that adoption of an OHSMS standard contributes to better financial performance for pharmaceutical firms of China in the short term. However, executives of pharmaceutical firms need to be aware of the increased costs related to certification renewal and audit in the following periods and exercise their management discretion to achieve a win-win situation between OHSMS implementation and financial benefit.

Keywords: occupational health and safety management system, OHSAS 18001, ISO 45001, financial performance, pharmaceutical firm

\section{Introduction}

In recent years, Chinese firms have been pressured by the public and the government to properly manager occupational health and safety (OHS) issues because of the increasing number of occupational accidents, illness, and injuries. ${ }^{1}$ There were 23,497 cases of occupational diseases reported in 2018, an increase of $103.98 \%$ compared with the number in $2006 .^{2}$ In particular, the manufacturing sector has a higher injury rate incurred because of relatively dangerous workplaces and hazardous production processes. In the Chinese context, the manufacturing sector has been
Faculty of Informatics and Management, University of Hradec Kralove,

Rokitanskeho 62, Hradec Kralove 50003,

Czech Republic

Tel +420737928745

Email petra.maresova@uhk.cz
Risk Management and Healthcare Policy 2020:I3 |477-|487

1477 
found to account for the largest group of occupational illness and injury cases, representing approximately $66 \%$ of injuries in all sectors. ${ }^{1}$ The details of the number of occupational disease cases and the death tolls from accidents related to workplace safety reported in China between 2006 and 2018 are shown in Table 1.

Belonging to manufacturing sector and with a focus on the promotion of well-being and public health, the pharmaceutical sector should do its best to contribute to corporate social responsibility $(\mathrm{CSR})^{3,4}$ and to satisfy moral demands from multiple stakeholders, such as patients, employees, the community, and government. ${ }^{5,6}$ Despite pharmaceutical firms having realised the importance of corporate citizenship, there has still been a growing number of occupational injuries, illnesses, or even fatalities during the last decade, which has had a harmful impact on the image of the whole sector. ${ }^{7-9}$ Taking China as an example, in April 2019, 10 workers died and 12 workers were seriously injured by an explosion in a pharmaceutical firm in Shandong province of mainland China. Another severe OHS accident was reported in June 2017 in Hunan province, where two workers were killed by a fire in a tincture plant. Table 2 illustrates some serious accidents related to OHS in Chinese pharmaceutical firms between 2010 and 2019.

Pharmaceutical firms need to exercise OHS issues in a more careful manner, not only because dangerous

Table I The Number of Occupational Disease Cases and the Death Tolls from Accidents Related to Workplace Safety Reported in China, 2006-2018

\begin{tabular}{|l|l|l|}
\hline Year & $\begin{array}{l}\text { The Reported Numbers } \\
\text { of Occupational Disease } \\
\text { Cases }\end{array}$ & $\begin{array}{l}\text { The Reported Death } \\
\text { Tolls from Accidents } \\
\text { Related to Workplace } \\
\text { Safety }\end{array}$ \\
\hline 2018 & 23,497 & 34,672 \\
2017 & 26,756 & 38,766 \\
2016 & 29,420 & 41,902 \\
2015 & 29,180 & 66,182 \\
2014 & 29,972 & 68,061 \\
2013 & 26,393 & 69,434 \\
2012 & 27,420 & 71,983 \\
2011 & 29,879 & 75,572 \\
2010 & 27,240 & 79,552 \\
2009 & 18,128 & 83,196 \\
2008 & 13,744 & 91,172 \\
2007 & 14,296 & 101,480 \\
2006 & 11,519 & 111,822 \\
\hline
\end{tabular}

Note: The source of the data is the National Health Commission of China. ${ }^{2}$
Table 2 Serious OHS Accidents in Pharmaceutical Firms in China, 2010-2019

\begin{tabular}{|c|c|c|}
\hline Year & Serious OHS Accident & Consequence \\
\hline 2019 & $\begin{array}{l}\text { An explosion at the freeze- } \\
\text { drying plant in Qilu-tianhe } \\
\text { Pharma in Shandong Province }\end{array}$ & $\begin{array}{l}\text { Ten workers died and } 12 \\
\text { workers were seriously } \\
\text { injured }\end{array}$ \\
\hline 2019 & $\begin{array}{l}\text { An explosion at the glutamine } \\
\text { production line in Shenhua } \\
\text { Pharma in Jiangsu Province }\end{array}$ & $\begin{array}{l}\text { Eight workers were injured } \\
\text { and one worker died after } \\
\text { being rescued }\end{array}$ \\
\hline 2018 & $\begin{array}{l}\text { A flash explosion within the } \\
\text { catalyst removal process of } \\
\text { hydrogenation in Yangzi } \\
\text { Pharma in Jiangsu Province }\end{array}$ & $\begin{array}{l}\text { One worker died and a loss } \\
\text { of } 1.4 \text { million Chinese yuan } \\
\text { was incurred }\end{array}$ \\
\hline 2017 & $\begin{array}{l}\text { A fire at the tincture plant in } \\
\text { Hansen Pharma in Hunan } \\
\text { Province }\end{array}$ & $\begin{array}{l}\text { Two workers died and three } \\
\text { workers were seriously } \\
\text { injured }\end{array}$ \\
\hline 2017 & $\begin{array}{l}\text { A fire at the Neurontin- } \\
\text { manufacturing plant in Tonghe } \\
\text { Pharma in Jiangxi Province }\end{array}$ & $\begin{array}{l}\text { One worker died and one } \\
\text { worker received minor } \\
\text { injuries }\end{array}$ \\
\hline 2015 & $\begin{array}{l}\text { A fire at the extraction plant } \\
\text { in Livzon Pharma in Ningxia } \\
\text { Autonomous Region }\end{array}$ & $\begin{array}{l}\text { Four workers suffered } \\
\text { burns; one of them suffered } \\
\text { severe burns }\end{array}$ \\
\hline 2014 & $\begin{array}{l}\text { An explosion of the drying } \\
\text { oven at the solid preparation } \\
\text { plant in Huigu Pharma in } \\
\text { Hainan Province }\end{array}$ & $\begin{array}{l}\text { Four workers died and } 10 \\
\text { workers were injured }\end{array}$ \\
\hline 2014 & $\begin{array}{l}\text { An explosion at the boiler in } \\
\text { Huayi Pharma in Zhejiang } \\
\text { Province }\end{array}$ & $\begin{array}{l}\text { Three workers were injured, } \\
\text { and the burned area was } \\
\text { over } 400 \text { square meters }\end{array}$ \\
\hline 2013 & $\begin{array}{l}\text { An explosion of the hot air } \\
\text { circulation oven in Tiancian } \\
\text { Pharma in Shanxi Province }\end{array}$ & $\begin{array}{l}\text { Five workers received minor } \\
\text { injuries }\end{array}$ \\
\hline 2012 & $\begin{array}{l}\text { An explosion in the reaction } \\
\text { cauldron in Ivyuan Pharma in } \\
\text { Hubei Province }\end{array}$ & $\begin{array}{l}\text { Two workers died and } 26 \\
\text { workers were injured }\end{array}$ \\
\hline 2011 & $\begin{array}{l}\text { An explosion of the } \\
\text { pressurised container in } \\
\text { Hanpu Pharma in Guangdong } \\
\text { Province }\end{array}$ & $\begin{array}{l}\text { One worker died and four } \\
\text { workers were seriously } \\
\text { injured }\end{array}$ \\
\hline 2010 & $\begin{array}{l}\text { An explosion at the tablet } \\
\text { plant in Quanxin Pharma in } \\
\text { Yunan Province }\end{array}$ & $\begin{array}{l}\text { Five workers died and eight } \\
\text { workers were injured, } \\
\text { including two workers who } \\
\text { suffered moderate burns }\end{array}$ \\
\hline
\end{tabular}

Note: The source of the data is the National Health Commission of China. ${ }^{2}$

workplaces may physically threaten workers' lives but also because chemical hazards and harmful discharges may potentially increase the risk to their health. ${ }^{10}$ The 
protection of OHS is a basic human right that the public require from government. ${ }^{11}$ Workplace safety is always regarded as a licence for a firm to operate sustainably in both legal and moral contexts.

\section{Relevance of OHSMS for Institutions}

To systematically reduce the number of lost workdays, the rates of accidents related to workplace safety, and costs related to occupational disease, some companies are likely to adopt an Occupational Health and Safety Management System (OHSMS). ${ }^{12-15}$ This system can effectively control OHS risks and improve safety management to such an extent that workers can better fulfil their duties with fewer safety concerns. ${ }^{16,17}$ The adoption of OHSMS may be triggered by pressure from various stakeholders involved in the firm. ${ }^{1}$ According to the institutional theory, the external environment can affect the development of the structure and the operational activities of an organisation. ${ }^{18}$ At present, firms are required to not just pursue economic benefit but to also ensure that they conform to the social systems of norms, rules, values, and beliefs. ${ }^{19}$ Under growing pressure for OHS protection by employees, the public, and government, firms may adjust their strategies and behaviours, such as adopting OHSMS, to meet external demands and secure their legitimacy. ${ }^{20}$

However, an OHSMS may lead to an "iron cage" for firms that adopt it if its implementation is driven by stakeholders' legitimacy rather than for internal technical benefit. ${ }^{21}$ In fact, institutional theory also suggests that the managerial decision for OHSMS implementation is made under a take-it-for-granted position from stakeholder pressure, whereby firms' internal efficiency and effectiveness may be hindered. ${ }^{18}$ Even so, some factors can facilitate the voluntary implementation of an OHSMS, closely linked to the introduction of a safety framework. ${ }^{22}$ Adopting firms can benefit from better control of occupational risk, reduction of accidents related to workplace safety, and decline of economic costs. ${ }^{23,24}$ They may also have reduced material losses and fewer interruptions in the production process. $^{25}$

Several extant studies have investigated OHSMS implementation in different geographic contexts. Using a sample of 131 firms from Spain, Fernández-Muñiz et $\mathrm{al}^{26}$ found that OHSMS adoption is driven by the prevention of work accidents, the promotion of employees' well-being, and firms' strategic needs. Similarly, Abad et $\mathrm{al}^{25}$ examined 149 Spanish firms and suggested that adopting firms have increased labour productivity. Based on data from seven manufacturing firms in Taiwan, Chen et $\mathrm{al}^{27}$ concluded that the factors of OHSMS adoption consist of internal decisions regarding corporate image and of external customer demand. In the Chinese context, Qi et $\mathrm{al}^{28}$ empirically examined OHSMS adoption from the management perspective and found that whether being publicly listed in the stock market is a significant driver for OHSMS adoption. Wang et $\mathrm{al}^{29}$ looked at 73 Chinese manufacturing firms during 2009-2012 to examine the association between OHSMS adoption and the efficiency of sustainability goals and concluded that firms adopting an OHSMS gain a higher triple-bottom-line efficiency score. Based on a sample of 211 US-listed firms in the manufacturing sector between 1999 and 2011, Lo et $\mathrm{al}^{30}$ found that adopting firms have better operating performance in terms of safety, sales' growth, labour productivity, and profitability.

\section{OHSMS Standards and Their Adoption}

To provide guidance for OHSMS adoption, some international bodies and institutions have published various OHSMS standards, such as ILO-OHS-2001, BS 8800, OHSAS 18001:2007 and ISO 45001:2018. ${ }^{25,31,32}$ Today, the Occupational Health and Safety Assessment Series (OHSAS) 18001:2007 and the ISO 45001:2008 are the two most commonly used standards in terms of OHS issues. ${ }^{32-36}$ The OHSAS 18001 has received considerable recognition worldwide, with approximately 90,000 adopting companies in 127 different countries, but it has been gradually replaced since Mar 2018 by a new OHS standard developed by the International Organization for Standardization (ISO), namely, the ISO $45001 .{ }^{37}$

Formulated in 1999, the OHSAS 18001 aims to promote good practice of OHS on the basis of a structured management system established in an organisation. ${ }^{38}$ It mainly addresses aspects of OHS without covering other health or sustainability issues like welfare programmes and cleaner manufacturing. Another prevailing OHSMS standard in recent years is the ISO 45001, which applies the common high-level structure of all ISO Management System Standards, like ISO 9001:2015 and ISO 14001:2015. The ISO 45001 utilises a continuous improvement cycle, such as the PDCA (Plan-Do-CheckAct) cycle, to develop OHS goals, evaluate OHS risks, monitor implemented OHS activities, and constantly improve OHS performance. ${ }^{37}$ It was initially developed on 12 March 2018, with a transition period of 36 months. Therefore, the existing OHSAS 18001 would not be valid 
after 11 March 2021, and all audits after then should be performed according to the requirement of the ISO $45001 .^{39}$

In general, both the OHSAS 18001 and the ISO 45001 provide instructions for companies to manage OHS risks and improve OHS performance. ${ }^{35-38}$ Even so, some differences still exist between standards. For instance, the ISO 45001 places greater emphasis on both internal and external factors related to OHS issues. Moreover, the ISO 45001 requires firms to take action to address OHS risks and opportunities that may both positively and negatively influence the capacity of an OHSMS. It also has a stronger focus on the role of top management in effectively exercising an OHSMS.

Nevertheless, the number of certified firms is growing rapidly around the world, the debate about whether the adoption can bring about benefits remains open, and researchers still claim that further study is needed to clarify the pros and cons of adoption of an OHSMS standard. ${ }^{23,30,31,40}$ One of the featured advantages for standard adoption is the organisational legitimacy gained from related stakeholders, including employees, customers, suppliers, and government. ${ }^{25,41,42}$ When OHS is promoted, adopting firms may have a greater possibility to retain and attract key personnel and, therefore, have increased labour productivity. ${ }^{20,25}$ Adopting firms can also charge premium prices for socially concerned customers, ${ }^{43}$ possibly resulting in expanded sales and better marketing performance. ${ }^{24,44}$ However, previous studies have determined that the adoption may lead to internal inefficiency and ineffectiveness. It can hardly result in superior performance when the pressures for standard adoption derive mainly from stakeholders, rather than from internal technical demands. ${ }^{24,30}$ Taken together, the abovementioned arguments are still inconclusive and need further justification.

\section{Research Question}

The research question of this paper lies in whether the adoption of an OHSMS standard could impact the financial performance of Chinese pharmaceutical firms. To the best of the authors' knowledge, very few studies have shed light on OHSMS standard adoption in the Chinese context, meaning that this study contributes to filling the research gap with empirical evidence of a country where firms have increasingly implemented an OHSMS. We also focus on the pharmaceutical industry, and few papers have addressed OHS issues in this particular sector. Another concern relates to the dominant amount of past studies relying on the use of subjective data (eg, surveys) in the empirical analysis. ${ }^{24,45}$ To overcome this bias, we measure adoption of an OHSMS standard objectively by using secondary data collected from an independent database.

The existing literature has pointed out that the impact of adoption of an OHSMS standard on financial performance is a gradual process because most OHSMS standards fall into a continuous improvement concept. ${ }^{24,25,29}$ In this vein, it is necessary to make a distinction between immediate and longrun effects of standard adoption. The institutional theory mentioned earlier leads us to deduce the hypotheses of this study. At a glance, adoption is financially burdensome because firms need to pay costly certification and audit expenses and may capitalise more funds to purchase safety facilities. ${ }^{46,47}$ However, employees could be also motivated to achieve better quality performance with fewer safety concerns. ${ }^{16}$ Under a sound OHS environment, accidents in the workplace can be also prevented to some extent. ${ }^{48}$ As indicated above, the adoption of an OHSMS standard may either positively or negatively impact financial performance in the short term. The first hypothesis is constructed as follows:

H1. The adoption of an OHSMS standard impacts contemporaneous financial performance among Chinese pharmaceutical companies.

In the long term, the adoption of an OHSMS standard may progressively foster a safer working climate where workers may carefully deal with production and inspection processes at a slower speed. Past studies have also concluded that an OHSMS standard could not serve as a strong marketing tool to attract customers. ${ }^{24}$ Nevertheless, previous studies have suggested that managers would perceive an OHSMS standard to be a strategic tool because, in the long-run, the adoption can provide competitive advantage and improve a firm's reputation. ${ }^{27}$ In this respect, the impact of OHSMS standard adoption on future financial performance still presents mixed results. ${ }^{25,49}$ Accordingly, the second hypothesis is defined as follows:

H2. The adoption of an OHSMS standard impacts subsequent financial performance among Chinese pharmaceutical companies.

\section{Research Methods Sample Selection}

The sample in this study is pharmaceutical firms currently listed on either the Shanghai or the Shenzhen stock exchanges, which are two main stock markets in mainland 
China. The sampling procedure consists of four stages. First, we identified 346 firms with a unique identification code of "Pharmaceutical Manufacturing" based on the "Industry Classification Guideline" published by the China Securities Regulatory Commission (CSRC). Second, we excluded those firms labelled as "Special Treatment (ST)" under CSRC's regulation between 2010 and 2018 because of the abnormality of their financial performance in consecutive years. Third, we removed firms with no prior certification records of any management system standard (eg, ISO 9001, ISO 14001 or OHSAS 18001) in a specialised certification database, namely the National Certification and Accreditation Information Public Service Platform (CAIPSP), during the analysed period. The reason for this exclusion was the difficulty of confirming whether a firm without past certification records would be included fully and in a timely fashion by the CAIPSP due to either renaming of the firm or other factors. Last, we eliminated firms with incomplete data of performance indicators.

The abovementioned sampling procedure finally resulted in a total of 125 pharmaceutical firms with 1,125 observations over a nine-year period from 2010 to 2018 . Table 3 reveals the stratification of sample firms by ownership structure and number of employees. In general, there is a significantly larger proportion of private pharmaceutical firms than of state-owned enterprises in the sample. Additionally, more than half of the sample firms have 1001 to 5000 employees. The full list of sample firms included in the study is shown in Appendix Table A1.

The data of OHSMS standard adoption for sample firms were obtained from the CAIPSP developed by the Certification and Accreditation Administration of the People's Republic of China (CNCA). This is an exclusive

Table 3 The Stratification of Sample Firms by Ownership Structure and Number of Employees

\begin{tabular}{|l|l|}
\hline & $\begin{array}{l}\text { Number (\%) of Sample } \\
\text { Firms }\end{array}$ \\
\hline $\begin{array}{l}\text { Ownership structure } \\
\text { Private }\end{array}$ & $87(69.60)$ \\
State-owned & $35(28.00)$ \\
Other (Privatising stated-owned) & $3(2.40)$ \\
\hline Number of employees & \\
Less than I,000 & $18(14.40)$ \\
Between I,00I and 5,000 & $73(58.40)$ \\
Between $5,00 \mathrm{I}$ and 10,000 & $2 \mathrm{I}(16.80)$ \\
More than 10,000 & $13(10.40)$ \\
\hline
\end{tabular}

database in China providing whether either a company or a specific type of product has been certified by a particular management system standard. Detailed information, such as the year of being certified and the agency granting the certification, can also be found in the database. Given that the CAIPSP has records for all adopting firms, we were able to manually evaluate whether and when a sample firm was certified by an OHSMS standard over the analysed period. Regarding the data of financial performance indicators, the source is the CSMAR (China Stock Market and Accounting Research) database, which is a leading capital market information provider offering extensive financial data of Chinese enterprises for academia.

\section{Measurements of Variables The Adoption of an OHSMS Standard}

The adoption of an OHSMS standard is the independent variable of this study. To measure whether a particular pharmaceutical firm adopts either the OHSAS 18001 or the ISO 45001, a dummy variable was developed by assigning the value of 1 if the sample firm is certified with the standard, and 0 otherwise. We also measured maximum two-year lagged terms of the independent variable because the sustaining impact of standard adoption on subsequent financial performance would be examined.

\section{Financial Performance and Control Variables}

Financial performance constitutes the dependent variables of this study. Orlitzky et $\mathrm{a}^{50}$ categorised three types of measure as accounting-based, market-based, and perpetual-based. We have not considered a perpetual-based measure as it is based on respondents' subjective perception of performance of a firm rather than on actual firm performance. Even though an accounting-based and market-based indicator is more objective, past studies have proved that focusing solely on a single type of measure may result in individual bias. ${ }^{51}$ For instance, the accounting-based measure is subject to past financial information, and the market-based measure may be easily affected by macroeconomic fluctuations. ${ }^{52}$ To overcome bias, we employed both accounting-based and market-based measures to comprehensively evaluate financial performance.

In terms of the accounting-based measure, we used return on assets (ROA) and return on equity (ROE), which have been commonly applied to measure profitability and included in studies related to adoption of a management system standard. ${ }^{24,41,53-55}$ Given that all sample firms in the study are listed on the stock exchange, Earnings per Share (EPS) is 
Table 4 Constructs of the Variables

\begin{tabular}{|l|l|}
\hline Variables & Measurement \\
\hline OHSMS & $\begin{array}{l}\text { A dummy variable I for firms adopting an OHSMS } \\
\text { standard; 0 for firms without adoption }\end{array}$ \\
ROA & $\begin{array}{l}\text { Return on assets = net income/total average assets } \\
\text { Return on equity = net income/total average equity }\end{array}$ \\
ROE & Earnings per share = (net income - preferred \\
& dividends)/weighted average shares outstanding \\
LNTA & Natural logarithm of total assets \\
\hline
\end{tabular}

proxied as a market-based measure because it can evaluate a listed firm's profit per outstanding share of stock. EPS is also frequently used in studies regarding management system standards and labour issues. ${ }^{56,57}$ Concerning the control variable, the natural logarithm of total assets is selected to modulate the size of the sample. The summary of variable measurements is shown in Table 4.

\section{Model Specification}

Panel data analysis is the main econometric approach we have used, as the study sample consists of a combination of time series and cross-sectional data. The Hausman specification test was initially run to determine the most appropriate statistical technique. ${ }^{58}$ Unlike previous studies of OHSMS standard adoption, where the random effects model was utilised directly, ${ }^{25}$ the independent variable of this study is a time-variant factor, in which no other timeinvariant variables are simultaneously involved. As such, the use of either the random effects or fixed effects model was dependent on the result of the Hausman specification test. The main model is proposed as follows:

$$
\begin{aligned}
& \text { Financialperformance }(R O A, R O E, E P S)_{i, t} \\
& \quad=\beta_{0}+\beta_{1} O H S M S_{i, t-m}+\beta_{2} L N T A_{i, t}+\varepsilon_{i, t}
\end{aligned}
$$

where Financialperformance $_{i, t}$ denotes the three equations related to ROA, ROE, and EPS of firm $i$ in year t. $O H S M S_{i, t-m}$ stands for the adoption of an OHSMS standard by firm $i$ in year $t$ - $m$, and $m=1, m=2$, representing the time frame for the subsequent effect of standard adoption on financial performance indicators. $L N T A_{i, t}$ is the natural logarithm of the total assets of firm $i$ in year $t$, and $\varepsilon_{i, t}$ is the disturbance term.

As the results of the empirical models could be incorrectly affected by collinearity, we initially computed the Variance Inflation Factor (VIF) to test whether parameter estimates in each regression model are amplified by correlations across the independent variables. The results of the diagnostic test revealed that the VIFs for all independent variables are under the commonly applied threshold of ten and, therefore, our models are workable without multicollinearity problems.

\section{Results}

Table 5 shows the number of sample firms certified with an OHSMS standard over the analysed period. In general, a growing number of Chinese pharmaceutical firms adopted the OHSAS 18001 standard between 2010 and 2017. Since 12 June 2018, some of the firms have been transiting from the OHSAS 18001 to the ISO 45001.

The descriptive statistics of all variables are shown in Table 6 . The mean value and the median value of OHSMS are 0.413 and 0 out of 1 , respectively, indicating that less than half of the observations show an OHSMS standard adoption between 2010 and 2018. All financial performance indicators, including ROA, ROE, and EPS, have negative signs in the minimum value, revealing that some of the firms experienced losses over the analysed period.

The correlation matrix for the dependent variables and independent variables is shown in Table 7. The results demonstrate that the variables of financial performance proxied by ROA, ROE, and EPS are all positively correlated with OHSMS at the 0.01 significance level. The

Table 5 The Number of Sample Firms Adopting an OHSMS Standard (Certified with the OHSAS I800I and the ISO 4500I), 2010-2018

\begin{tabular}{|l|l|l|l|l|l|l|l|l|l|}
\hline Indices & 2010 & 2011 & 2012 & 2013 & 2014 & 2015 & 2016 & 2017 & 2018 \\
\hline $\begin{array}{l}\text { Number of sample firms } \\
\text { with the OHSAS I800I } \\
\text { certification } \\
\begin{array}{l}\text { Number of sample firms } \\
\text { with the ISO 4500I } \\
\text { certification }\end{array}\end{array} 23$ & 25 & 37 & 53 & 68 & 82 & 88 & 89 & $\begin{array}{l}89 \text { (5 firms transited to the ISO 4500I since } \\
\text { I2 June 20I8) }\end{array}$ \\
\hline
\end{tabular}


Table 6 Descriptive Statistics

\begin{tabular}{|l|l|l|l|l|l|l|l|}
\hline Variables & No. of Observations & Median & Mean & Min. & Max. & SD & Skewness \\
\hline OHSMS & $\mathrm{I} I 25$ & 0.000 & 0.413 & 0.000 & 1.000 & 0.709 & 0.1 .937 \\
ROA & $\mathrm{I} I 25$ & 0.074 & 0.068 & -0.459 & 0.354 & 0.084 & 0.047 \\
ROE & $\mathrm{I} I 25$ & 0.109 & 0.077 & -0.393 & 1.357 & 0.147 & 3.969 \\
EPS & $\mathrm{I} I 25$ & 0.595 & 0.516 & -0.610 & 3.021 & 0.583 & 1.307 \\
LNTA & $\mathrm{I} I 25$ & 21.304 & 21.101 & 19.016 & 23.558 & 0.930 & 0.184 \\
\hline
\end{tabular}

Table 7 Correlation Analysis

\begin{tabular}{|l|l|l|l|l|l|}
\hline & ROA & ROE & EPS & LNTA & OHSAS \\
\hline ROA & 1 & & & & \\
ROE & $0.903 * * *$ & 1 & & & \\
EPS & $0.676 * * *$ & $0.695 * * *$ & 1 & & \\
LNTA & $0.037 *$ & $0.292 * * *$ & $0.570 * * *$ & 1 & \\
OHSMS & $0.452 * * *$ & $0.288 * * *$ & $0.324 * * *$ & $0.275 * * *$ & 1 \\
\hline
\end{tabular}

Notes: $* * * p<0.01 ; * p<0.10$

coefficients fall into the range between 0.275 and 0.452 , indicating that Chinese pharmaceutical firms with better financial performance may adopt an OHSMS standard more frequently.

In the following panel-based regression models, we examined whether adoption of an OHSMS standard affects contemporaneous financial performance and has a subsequent impact on future financial performance. The Hausman specification test was first implemented to examine whether fixed effects exist. We found statistically significant results between OHSMS with ROA and OHSMS with EPS; thus the fixed effects models are applicable. We also found insignificant results between OHSMS with ROE; therefore, we have used the random effects model.

Table 8 shows the impact of OHSMS standard adoption on contemporaneous financial performance. The empirical results demonstrate that over the analyzed period and between firms, the coefficients between OHSMS and financial performance indicators were significantly positive. To be specific, ROA was found to increase by 2.37 percentage points when firms adopt an OHSMS standard, whereas ROE experienced a relatively higher increase, of 6.15 percentage points. EPS was enhanced by 3.59 percentage points for those firms that adopted the standard. This suggests that in the context of China, pharmaceutical firms adopting an OHSMS standard have better financial performance, and so $\mathrm{H} 1$ is supported. Our findings are in line with previous studies conducted for enterprises in Spain $^{25}$ and manufacturing companies in the U.S., ${ }^{30}$ but they are contrary to those of a study of US
Table 8 Regression Models: Effect of OHSMS on Contemporaneous Financial Performance

\begin{tabular}{|l|l|l|l|}
\hline \multirow{2}{*}{$\begin{array}{l}\text { Independent variable } \\
\text { OHSMS }\end{array}$} & \multicolumn{3}{l|}{ Dependent Variables } \\
\cline { 2 - 4 } & ROA & ROE & EPS \\
\hline $\begin{array}{l}\text { Control variable } \\
\text { Size }\end{array}$ & $0.0237^{* * *}$ & $0.0615^{* *}$ & $0.0359^{* *}$ \\
Constant & 0.0359 & -0.0019 & $0.5764^{* *}$ \\
Adjusted R & $0.1316^{* * *}$ & 0.0075 & $0.0578^{* *}$ \\
F-statistics & 0.3958 & 0.0102 & 0.6026 \\
Durbin-Watson & $6.4340^{* * *}$ & 3.853 & $8.5542^{* * *}$ \\
Hausman specification test & 1.7091 & 2.8329 & 1.8371 \\
Observations & $25.684 \mathrm{I} * * *$ & 1.952 & $23.972 * * *$ \\
\hline
\end{tabular}

Notes: $*^{* *} p<0.01$; $*_{p}<<0.05$; The $95 \% \mathrm{Cl}: \mathrm{ROA}$ as dependent variable $(0.0196,0.0279)$, ROE as dependent variable $(0.0493,0.0738)$, EPS as dependent variable $(0.0151,0.0567)$.

Abbreviations: ROA, return on assets; ROI, return on equity; EPS, earnings per share; LNTA, natural logarithm of total assets; $\mathrm{Cl}$, confidence interval.

fashion and textile companies where OHSMS standard adoption was found to be negatively related to ROA. ${ }^{24}$

Table 9 shows the influence of OHSMS adoption on subsequent financial performance. For one-year lagged OHSMS, mixed empirical results were obtained because there was a positive coefficient with ROE at the 5\% significance level, but there was no significant relationship with both ROA and EPS. Over the analysed period and between firms, one-year subsequent ROE will increase by 2.75 percentage points as firms adopt an OHSMS standard. A two-year lagged OHSMS had a negative association with EPS at the 5\% significance level, but it had no significant effect on both ROA and ROE. To be specific, firms with OHSMS standard adoption may experience a decrease in EPS by 2.96 percentage points in the third year after certification and experience no significant change in other financial performance indicators. In light of the above results, OHSMS standard adoption by pharmaceutical firms has an impact on subsequent financial performance, so $\mathrm{H} 2$ is also confirmed. 
Table 9 Regression Models: Effect of OHSMS on Subsequent Financial Performance

\begin{tabular}{|c|c|c|c|c|c|c|}
\hline & \multicolumn{6}{|c|}{ Dependent Variables } \\
\hline & ROA & ROE & EPS & ROA & ROE & EPS \\
\hline Time Lag & \multicolumn{3}{|l|}{$t-I$} & \multicolumn{3}{|l|}{$t-2$} \\
\hline \multicolumn{7}{|l|}{ Independent variable } \\
\hline $\mathrm{OHSMS}_{t-1}$ & 0.0194 & $0.0275 * *$ & -0.0605 & & & \\
\hline $\mathrm{OHSMS}_{t-2}$ & & & & -0.0318 & -0.0193 & $-0.0296 * *$ \\
\hline \multicolumn{7}{|l|}{ Control variable } \\
\hline Size & 0.0315 & $0,0194 *$ & $0.2691^{* * * *}$ & 0.0194 & 0.0258 & $0.4740 * * *$ \\
\hline Constant & 0.1052 & 0.0957 & $-0.1335 * * *$ & 0.0498 & 0.0057 & $-0.2887 * *$ \\
\hline Adjusted $\mathrm{R}^{2}$ & 0.3817 & 0.0012 & 0.5679 & 0.3919 & 0.0003 & 0.5957 \\
\hline F-statistics & $4.1328 * * *$ & 1.6739 & $8.0195^{* * * *}$ & $4.6072^{* * *}$ & 1.0683 & $8.734 * * *$ \\
\hline Durbin-Watson & $\mathrm{I} .6475$ & 1.9726 & 1.5903 & 1.8140 & 1.3847 & 1.9522 \\
\hline Hausman test & $38.4104 * * *$ & 2.8505 & $35.2367^{* * *}$ & $38.3893 * * *$ & 2.7424 & $39.9602 * * *$ \\
\hline Observations & 1125 & 1125 & 1125 & 1125 & 1125 & 1125 \\
\hline
\end{tabular}

Notes: $*^{* *} p<0.01$; $* * p<0.05 ; *_{p}<0.10$; The $95 \% \mathrm{Cl}$ : t-I model, ROA as independent variable $(0.0017,0.0372)$, ROE as independent variable $(0.0095,0.0456)$, EPS as independent variable $(-0.1508,0.0297)$; $\mathrm{t}-2$ model, ROA as independent variable $(-0.1076,0.0440)$, ROE as independent variable $(-0.0234,-0.0152)$, EPS as independent variable $(-0.07 \mid 8,0.0125)$.

Abbreviations: ROA, return on assets; ROI, return on equity; EPS, earnings per share; LNTA, natural logarithm of total assets; Cl, confidence interval.

As a summary, we conclude that firms with either the OHSAS 18001 or the ISO 45001 certification will have better financial performance proxied by ROA, ROE, and EPS. When extending financial performance indicators by a year, only ROE is significantly and positively related. Nevertheless, a negative and statistically significant coefficient for EPS is found when financial performance indicators are extended by two years.

\section{Discussion}

This research aims to provide empirical evidence of the impact of OHSMS standard adoption on the financial performance of pharmaceutical firms in China. From the cost-effectiveness point of view, the pros may outweigh the cons because all financial performance indicators of the year will increase as the firm successfully certifies with an OHSMS standard. These revealing findings are reinforced by the institutional theory, which suggests that adopting an OHSMS standard helps firms improve their relationship with employees and both retain and attract key personnel. ${ }^{20}$ When employees feel safe and stay healthy, they can be actively motivated and have better job performance. Employees' higher satisfaction in relation to the workplace and increased wellbeing may directly lead to greater labour productivity. ${ }^{16}$ The adoption of an OHSMS standard also leads to lower rate of working accidents, fewer interruptions of the production process, and less wasted effort. ${ }^{48}$ Therefore, the adoption may positively affect the financial performance over the year through the improvement of operating efficiency. ${ }^{54}$

In terms of whether OHSMS standard adoption will sustainably influence subsequent financial performance, only ROE shows a statistically significant increase in the second year after the firm is certified. We argue that to some extent, gaining legitimacy through the standard adoption could provide a better opportunity for pharmaceutical firms to attract customers and improve their corporate image and, thus, gradually achieve better future financial performance. However, EPS may decrease in the third year after certification. The possible reason for the statistically significant decline in this performance indicator is that the certification must be renewed every three years. ${ }^{41}$ This will inevitably incur more costs related to renewal and audit, potentially detracting from firms' valuable financial resources.

The findings of this section complement the extant literature, suggesting the following two key points: first, in the context of the pharmaceutical sector of China, the adoption of an OHSMS standard could contribute to better financial performance; second, as OHSMS standards fall into a continuous improvement concept, standard adoption will constantly affect subsequent financial performance indicators. We also infer that the positive impact of the adoption may either gradually weaken or even vanish, probably due to the increasing costs of certification renewal, auditing, or other activities in the 
third year after the firm is certified. This finding further justifies Fan et al's study, ${ }^{24}$ which proposed that the adoption of an OHSMS standard may create some operational and financial constraints, potentially deteriorating firms' profitability in the long run.

\section{Conclusions}

To summarise, this study contributes to an inconclusive yet popular debate regarding the impact of the adoption of an Occupational Health and Safety Management System (OHSMS) standard on financial performance. We test whether contemporaneous and subsequent firm performance can benefit from standard adoption in the context of the Chinese pharmaceutical industry. By using a sample of 125 listed pharmaceutical firms over a sample period from 2010 to 2018, the positive effect of OHSMS standard adoption on contemporaneous return on assets, return on equity (ROE), and earnings per share (EPS), as the proxies of financial performance, is confirmed. However, we obtain mixed results are found when we extend financial performance indicators by two years, suggesting that ROE will increase in the second year after the firm is certified, but EPS will decline in the third year. Our study adds to the extant literature as it not only provides empirical evidence of a country in which related research efforts have been scarce but also uses secondary data to objectively examine the impact of OHSMS standard adoption over time.

Some companies would hesitate to adopt an OHSMS standard, as managers may consider the certification to be a waste of valuable financial resources and to lead to technical inefficiency due to the increased complexity of internal processes. Especially for the pharmaceutical sector, firms may feel financial pressure to carry out corporate social responsibility and occupational health and safety practices because R\&D and medication promotional activities are always emphasised. ${ }^{6}$ Nevertheless, the empirical findings of this study suggest that executives of pharmaceutical firms need to realise the importance of OHS and exercise their management discretion to achieve a winwin situation between OHSMS implementation and financial benefit. Policy makers also need to set out some initiatives to increase firms' contributions towards OHS issues.

We acknowledge some limitations of this study. First, as the empirical models cover only two-year lagged terms, the time frame for the subsequent effect of standard adoption is insufficiently long because the certification renewal process would be carried out every three years. Second, the financial performance indicators used in this study are not sufficient to broadly measure all economic aspects of a firm. Future research could consider the operating perspective of performance measures like innovation and growth capacity and expand to include different industry sectors and other emerging economies.

\section{Abbreviations}

OHS, Occupational Health and Safety; OHSMS, Occupational Health and Safety Management System; CSR, Corporate Social Responsibility; OHSAS, Occupational Health and Safety Assessment Series; ISO, International Organization for Standardization; PDCA, Plan-Do-Check-Act; CAIPSP, National Certification and Accreditation Information Public Service Platform; CNCA, Certification and Accreditation Administration of the People's Republic of China; CSMR, China Stock Market and Accounting Research; CSRC, China Securities Regulatory Commission; ST, special treatment; ROA, return on assets; ROE, return on equity; EPS, earnings per share; VIF, variance inflation factor; CI, confidence interval.

\section{Data Sharing Statement}

The dataset analysed and used to support the findings of this study is available from the authors upon request.

\section{Ethical Approval}

This study does not require ethical approval, because we used secondary data that are freely accessible.

\section{Acknowledgments}

This research was funded by the internal project Excellence 2020, Faculty of Informatics and Management, University of Hradec Kralove, Czech Republic.

\section{Disclosure}

The authors report no conflicts of interest in this work.

\section{References}

1. Sui Y, Ding R, Wang H. An integrated management system for occupational health and safety and environment in an operating nuclear power plant in East China and its management information system. J Clean Prod. 2018;183:261-271. doi:10.1016/j.jclepro.2018. 02.101

2. National Health Commission of China. The report of health China of 2019. 2019. Available from: http://www.nhc.gov.cn/guihuaxxs/ jkzgxdzt/xkzgxd.shtml. Accessed July 15, 2019. 
3. Mehralian G, Nazari JA, Zarei L, Rasekh HR. The effects of corporate social responsibility on organizational performance in the Iranian pharmaceutical industry: the mediating role of TQM. J Clean Prod. 2016;135:689-698. doi:10.1016/j.jclepro.2016.06.116

4. Malik MS, Kanwal L. Impact of corporate social responsibility disclosure on financial performance: case study of listed pharmaceutical firms of Pakistan. J Bus Ethics. 2018;150(1):69-78. doi:10.1007/ s10551-016-3134-6

5. Esteban D. Strengthening corporate social responsibility in the pharmaceutical industry. J Med Mark. 2008;8(1):77-79. doi:10.1057/palgrave.jmm.5050126

6. Yang M, Bento P, Akbar A. Does CSR influence firm performance indicators? Evidence from Chinese pharmaceutical enterprises. Sustainability. 2019;11:5656. doi:10.3390/su11205656

7. Scott AJ. Occupational health in the pharmaceutical industry: an overview. Occup Med. 2003;53(6):354-356. doi:10.1093/occmed/ kqg114

8. Li S, Li T, Li JG, Chen L, Ren J, Li CL. A comprehensive evaluation of intervention effects on workplace health promotion in a pharmaceutical company. Chinese J Indv Hygiene Occup Dis. 2012;30(2):115-118.

9. Rasouli A, Hosseini SM, Bahadori M, Ravangard R. Characteristics of occupational injuries in a pharmaceutical company in Iran. Bull Emerg Trauma. 2018;6(2):155-161. doi:10.29252/beat-060210

10. Wu J, Du K. The occupational health safety management system and innovation of enterprise. Acct Forum. 2018;7:96-121.

11. Pagell M, Johnston D, Veltri A, Klassen RD, Biehl M. Is safe production an oxymoron? Prod Oper Manag. 2014;23 (7):1161-1175. doi:10.1111/poms.12100

12. Jallon R, Imbeau D, de Marcellis-warin N. Development of an indirect-cost calculation model suitable for workplace use. $J$ Saf Res. 2011;42(3):149-164. doi:10.1016/j.jsr.2011.05.006

13. Autenrieth D, Brazile WJ, Sandfort DR, Douphrate DI, Romanmuniz IN, Reynolds SJ. The associations between occupational health and safety management system programming level and prior injury and illness rates in the U.S. dairy industry. Saf Sci. 2016;84:108-116. doi:10.1016/j.ssci.2015.12.008

14. Gopang MA, Nebhwani M, Khatri A, Marri HB. An assessment of occupational health and safety measures and performance of SMEs: an empirical investigation. Saf Sci. 2017;93:127-133. doi:10.1016/j. ssci.2016.11.024

15. Inan UH, Gul S, Yilmaz H. A multiple attribute decision model to compare the firms' occupational health and safety management perspectives. Saf Sci. 2017;91:221-231. doi:10.1016/j.ssci.2016.08.018

16. Das A, Pagell M, Behm M, Veltri A. Toward a theory of the linkages between safety and quality. J Oper Manag. 2008;26(4):521-535. doi:10.1016/j.jom.2007.06.005

17. de Oliveira Matias JCD, Coelho DA. The integration of the standards systems of quality management, environmental management and occupational health and safety management. Int $J$ Prod Res. 2002;40(15):3857-3866. doi:10.1080/00207540210155828

18. Meyer JW, Rowan B. Institutionalized organizations: formal structure as myth and ceremony. Am J Sociol. 1977;83(2):340-363. doi:10.1086/226550

19. Scott R. Institutions and Organizations. Thousand Oaks: Sage Publications; 1995.

20. Suchman MC. Managing legitimacy: strategic and institutional approaches. Acad Manag Rev. 1995;20(3):571-610. doi:10.5465/ amr.1995.9508080331

21. Dimaggio P, Powell WW. The iron cage revisited: institutional isomorphism and collective rationality in organizational fields. $\mathrm{Am}$ Sociol Rev. 1983;48(2):143-166. doi:10.2307/2095101

22. Hart SM. Self-regulation, corporate social responsibility, and the business case: do they work in achieving workplace equality and safety? $J$ Bus Ethics. 2010;92(4):585-600. doi:10.1007/s10551-009-0174-1
23. Robson LS, Clarke JA, Cullen K, et al. The effectiveness of occupational health and safety management system interventions: a systematic review. Saf Sci. 2007;45(3):329-353. doi:10.1016/j. ssci.2006.07.003

24. Fan D, Lo CK. A tough pill to swallow? The impact of voluntary occupational health and safety management system on firms' financial performance in fashion and textiles industries. $J$ Fashion Mark Manag. 2012;16(2):128-140. doi:10.1108/13612021211222798

25. Abad J, Lafuente E, Vilajosana J. An assessment of the OHSAS 18001 certification process: objective drivers and consequences on safety performance and labour productivity. Saf Sci. 2013;60:47-56. doi:10.1016/j.ssci.2013.06.011

26. Fernández-Muñiz B, Montes-Peón JM, Vázquez-Ordás CJ. Occupational risk management under the OHSAS 18001 standard: analysis of perceptions and attitudes of certified firms. J Clean Prod. 2012;24(24):36-47. doi:10.1016/j.jclepro.2011.11.008

27. Chen CY, Wu GS, Chuang KJ, Ma CM. A comparative analysis of the factors affecting the implementation of occupational health and safety management systems in the printed circuit board industry in Taiwan. J Loss Prevent Proc. 2009;22(2):210-215. doi:10.1016/j. jlp.2009.01.004

28. Qi G, Zeng S, Yin H, Lin H. ISO and OHSAS certifications: how stakeholders affect corporate decisions on sustainability. Manag Dec. 2013;51(10):1983-2005. doi:10.1108/MD-11-2011-0431

29. Wang X, Lin H, Weber O. Does adoption of management standards deliver efficiency gain in firms? Pursuit of sustainability performance? An empirical investigation of Chinese manufacturing firms. Sustainability. 2016;8(7):1-18. doi:10.3390/su8070694

30. Lo CK, Pagell M, Fan D, Wiengarten F, Yeung ACL. OHSAS 18001 certification and operating performance: the role of complexity and coupling. J Oper Manag. 2014;32(5):268-280. doi:10.1016/j. jom.2014.04.004

31. Lafuente E, Abad J. Analysis of the relationship between the adoption of the OHSAS 18001 and business performance in different organizational contexts. Saf Sci. 2018;103:12-22. doi:10.1016/j.ssci.2017.11.002

32. Ghahramani A, Salminen S. Evaluating effectiveness of OHSAS 18001 on safety performance in manufacturing companies in Iran. Saf Sci. 2019;112:206-212. doi:10.1016/j.ssci.2018.10.021

33. Granerud L, Rocha RS. Organisational learning and continuous improvement of health and safety in certified manufacturers. Saf Sci. 2011;49(7):1030-1039. doi:10.1016/j.ssci.2011.01.009

34. Halíčková K, Basovníková M, Pavlíková EA. The implementation of the occupational health and safety management at work and its influence on the economic performance of the company. Acta Universitatis Bohemiae Meridionalis. 2016;19:50-58. doi:10.1515/ acta-2016-0010

35. Fernández-Muñiz B, Montes-Peón JM, Vázquez-Ordás CJ. Safety climate in OHSAS 18001-certified organisations: antecedents and consequences of safety behavior. Accident Anal Prev. 2012;45:745-758. doi:10.1016/j.aap.2011.10.002

36. Karapetrovic S, Casadesús M. Implementing environmental with other standardized management systems: scope, sequence, time and integration. J Clean Prod. 2009;17(5):533-540. doi:10.1016/j. jclepro.2008.09.006

37. International Organization for Standardization. ISO 45001 occupational health and safety management systems-requirement. 2018. Available from: https://www.iso.org/iso-45001-occupational-healthand-safety.html. Accessed September 20, 2018.

38. British Standards Institution. OHSAS 18001: occupational health and safety management systems-requirement. 2007. Available from: https://www.bsigroup.com/en-US/OHSAS-18001-OccupationalHealth-and-Safety/. Accessed August 10, 2020.

39. Morgado L, Silva FJ, Fonseca LM. Mapping occupational health and safety management systems in Portugal: outlook for ISO 45001:2018 adoption. Procedia Manuf. 2019;38:755-764. doi:10.1016/j. promfg.2020.01.103 
40. Argilesbosch JM, Marti J, Monllau T, Garciablandon J, Urgell T. Empirical analysis of the incidence of accidents in the workplace on firms' financial performance. Saf Sci. 2014;70:123-132. doi:10.1016/ j.ssci.2014.05.012

41. Hernandez-Vivanco A, Domingues P, Sampaio P, Bernardo M, CruzCázares C. Do multiple certifications leverage firm performance? A dynamic approach. Int $J$ Prod Econ. 2019;218:386-399. doi:10.1016/j.ijpe.2019.07.016

42. Staw BM, Epstein LD. What bandwagons bring: effects of popular management techniques on corporate performance, reputation, and CEO pay. Adm Sci Q. 2000;45(3):523-556. doi:10.2307/2667108

43. Montero MJ, Araque RA, Rey JM. Occupational health and safety in the framework of corporate social responsibility. Saf Sci. 2009;47 (10):1440-1445. doi:10.1016/j.ssci.2009.03.002

44. Law WK, Chan AHS, Pun KF. Prioritising the safety management elements: a hierarchical analysis for manufacturing enterprises. Ind Manag Data Syst. 2006;106(6):778-792. doi:10.1108/02635570610671470

45. Heras-Saizarbitoria I, Molina-Azorín JF, Dick GPM. ISO 14001 certification and financial performance: selection-effect versus treatment-effect. J Clean Prod. 2011;19:1-12. doi:10.1016/j. jclepro.2010.09.002

46. Lingard H, Rowlinson SM. Occupational Health and Safety in Construction Project Management. Boca Raton: Taylor \& Francis; 2005.

47. Wang H, Lu W, Ye M, Chau KW, Zhang X. The curvilinear relationship between corporate social performance and corporate financial performance: evidence from the international construction industry. $J$ Clean Prod. 2016;137:1313-1322. doi:10.1016/j.jclepro.2016.07.184

48. Tsai WH, Chou WC. Selecting management systems for sustainable development in SMEs: a novel hybrid model based on DEMATEL, ANP, and ZOGP. Expert Syst Appl. 2009;36:1444-1458. doi:10.1016/ j.eswa.2007.11.058
49. Lo CKY, Yeung ACL, Cheng TCE. Meta-standards, financial performance and senior executive compensation in China: an institutional perspective. Int J Prod Econ. 2011;129(1):119-126. doi:10.1016/j. ijpe.2010.09.011

50. Orlitzky M, Rynes SL, Schmidt FL. Corporate social and financial performance: a meta-analysis. Organ Stud. 2003;24(3):403-441. doi:10.1177/0170840603024003910

51. McGuire JB, Sundgren A, Schneeweis T. Corporate social responsibility and firm financial performance. Acad Manag J. 1988;31:854-872.

52. Ullmann A. Data in search of a theory: a critical examination of the relationships among social performance, social disclosure, and economic performance. Acad Manag Rev. 1985;10(3):540-557.

53. Corbett CJ, Montes-Sancho MJ, Kirsch DA. The financial impact of ISO 9000 certification in the United States: an empirical analysis. Manag Sci. 2005;51:1046-1059. doi:10.1287/mnsc.1040.0358

54. He W, Liu C, Lu J, Cao J. Impacts of ISO 14001 adoption on firm performance: evidence from China. China Econ Rev. 2015;32:43-56. doi:10.1016/j.chieco.2014.11.008

55. Casadesús M, Marimon F, Heras I. ISO 14001 diffusion after the success of the ISO 9001 model. J Clean Prod. 2008;16 (16):1741-1754. doi:10.1016/j.jclepro.2007.11.002

56. Sharma DS. The association between ISO 9000 certification and financial performance. Int $J$ Account. 2005;40(2):151-172. doi:10.1016/j.intacc.2005.01.011

57. Schneider B, Hanges PJ, Smith DB, Salvaggio AN. Which comes first: employee attitudes or organizational financial and market performance? J Appl Psychol. 2003;88(5):836-851. doi:10.1037/ 0021-9010.88.5.836

58. Hausman JA. Specification tests in econometrics. Econometrica. 1978;46(6):1251-1271. doi:10.2307/1913827
Risk Management and Healthcare Policy

\section{Publish your work in this journal}

Risk Management and Healthcare Policy is an international, peerreviewed, open access journal focusing on all aspects of public health, policy, and preventative measures to promote good health and improve morbidity and mortality in the population. The journa welcomes submitted papers covering original research, basic science, clinical \& epidemiological studies, reviews and evaluations, guidelines, expert opinion and commentary, case reports and extended reports. The manuscript management system is completely online and includes a very quick and fair peer-review system, which is all easy to use. Visit http://www.dovepress.com/testimonials.php to read real quotes from published authors. 